ORIGINAL ARTICLE

\title{
Feminization and Labor Vulnerability in Global Manufacturing Industries: Does Gendered Discourse Matter?
}

\author{
Md. Ismail Hossain ${ }^{1,2}$, Golam M. Mathbor ${ }^{3}$ and Renata Semenza ${ }^{1}$ \\ ${ }^{1}$ Department of Social and Political Sciences, University of Milan, Milan, Italy; \\ 2 Department of Social Work, Shahjalal University of Science \& Technology, Sylhet, Bangladesh; \\ ${ }^{3}$ School of Social Work, Monmouth University, West Long Branch, New Jersey, USA
}

Two contested arguments persist in explaining the causes of feminization and labor vulnerability. Some scholars argue that global industries are dominated by female workers as a result of the search for cheap labor. On the other hand, some scholars claim that the primary cause of feminization and labor vulnerability is the gendered discourses of work. Drawing views from readymade garment (RMG) industries of Bangladesh, this paper argues that both economic choices of cheap labor and gendered discourses of work collaboratively contribute to feminizing the labor force. This feminization of the workforce enables the violation of labor rights and benefits capitalists.

Keywords feminization; flexible labor; gendered discourse; globalization; manufacturing industry doi:10.1111/aswp.12018

\section{Introduction}

Academic discussion about the feminization of the workforce in global manufacturing industries has gained momentum. As multinational corporations (MNCs) relocate their firms to developing countries, ${ }^{1}$ women have gained increased access to industrial jobs. Scholars have argued that the increase in the feminized workforce has happened as a result of searching for cheap labor (Elson \& Pearson, 1981; Nash \& Fernandez-Kelly, 1983; Standing, 1989) and this has lead to labor exploitation. On the contrary, some scholars (Caraway, 2005; Marchand \& Runyan, 2000; Razavi, 2002) have argued that economic views of feminization undermine the influence of gendered discourses about labor. They have claimed that global manufacturing industries' preference for female workers does not merely happen as a result of searching for cheap labor; rather, gendered discourses of labor are the main influencing factor for feminization of the labor

Correspondence concerning this article should be addressed to Md. Ismail Hossain, Department of Social Work, Shahjalal University of Science \& Technology, Sylhet 3114, Bangladesh. Email: ismail-scw@sust.edu

${ }^{1}$ This refers to countries whose economy is comparatively weaker than other countries in the world and mainly dependent on traditional agriculture-based production with abundant supply of unskilled labor. 
force. The gendered discourses of labor refer to the gender-biased beliefs that provide distinct forms of labor for men and women. These beliefs justify labor exploitation and gender discrimination at the workplace (Caraway, 2005). While agreeing with these two dominant views, this paper argues that both "economic choices of cheap labor" and "gendered discourses of work" jointly enforce the feminized pattern of the labor force and lead to the violation of labor rights that serve the economic motive of cheap labor.

\section{Feminization and labor vulnerability in the global manufacturing}

Generally, feminization of the workforce entails mass entry of women into the formal labor force (Momen, 2006). This concept became the center of academic discussion after the publication of Ester Boserup's book Women's Role in Economic Development (1970). The term "feminization of labor" is mainly used to denote two different features. First, it is used to refer to the sharp increase in women's labor force participation, particularly in a shift from the agricultural to the industrial sector. Second, the term "feminization of labor" is used to describe increased flexibility in men and women's labor. "Flexible labor" refers to temporary employment patterns that are constituted by part-time and casual workers. Employers with flexible workforces employ more workers when they have higher production volumes and reduce the workforce when they have small volumes of production. Limited job opportunities for women combined with urgent family needs often force women to work in these global industries even though employment is on a temporary basis. Thus, a flexible workforce is mostly constituted by poor women (Standing, 1989). Both of these features are strongly conjoined and directly influenced by globalization and economic liberalization. The rise of "multinational corporations" (MNCs) is also an eventual outcome of globalization. MNCs relocate firms to developing countries where the supply of cheap labor is abundant. The pressure of global competition forces employers to substitute men's labor with cheap female labor to keep unit costs down (Standing, 1989). With the expansion of exportoriented manufacturing in many low-income countries and labor-surplus economies, many women have an opportunity to enter the labor market through feminized employment strategies, which cause a sharp rise in women in employment (Barrientoes \& Kabeer, 2004; Kanji \& Sen, 2001). With the advancement of technological innovation, there is a global trend to reduce reliance on full-time wage and salary workers who earn fixed wages and benefits (Islam, 2008).

"Feminization" and "flexibility" form a twofold process involving the increased labor force participation of women and an increase in non-standard jobs typically associated with women, such as part-time, temporary, poorly paid and insecure jobs (Standing, 1989). The increasing competition in global markets leads MNCs toward a mixed labor force constituted by both full-time and part-time workers. Mixed labor legally frees MNCs from providing labor benefits, which helps keep production costs down. This flexible labor force is mainly formed by female workers due to their secondary status in the market (Standing, 1989). Women are considered the "reserve labor force" that can easily 
be hired and fired depending on the needs of the factory (Elson \& Pearson, 1997). According to Lim (1997), the term "reserve labor force", strains the socially constructed mythical roles of "male breadwinners" and "female caregivers", which places sole responsibility on the male for financial needs and the female for caring for the children and other family members. Thus, any income earned by the female is considered extra support for the family. Furthermore, the supply of female labor is abundant due to their often limited scope of employment and the comparatively better wages and secured work environment of the factory compared with other traditional sources of female employment (Lim, 1997).

Many feminist scholars (Elson \& Pearson, 1981; Lim, 1997; Safa, 1986) argue that feminization is the inevitable consequence of searching for cheap labor to reduce production costs. By departing slightly from this argument, some scholars (Caraway, 2005; Marchand \& Runyan, 2000; Razavi, 2002) have argued that gendered discourses of work are more important for feminization and exploitation of labor than the economic forces of cheap labor. Neither of these arguments has properly perceived the influence of gendered discourses of work. This paper argues that gendered discourses of work contribute to the feminization of the workforce and to violations of labor rights through which the economic motives of cheap labor are served. Thus, the main purpose of this paper is to explore which gendered discourses are practised in global manufacturing industries and how these discourses contribute to the feminization and exploitation of labor along with economic choices of cheap labor.

\section{Data sources and research methods}

This paper is based on the findings of an empirical study conducted in the readymade garment (RMG) industry in Dhaka, the capital of Bangladesh, during the period of October 2011-June 2012. The main reason for selecting Dhaka City as an empirical site is that it is the location of approximately $80 \%$ of the total RMG factories in Bangladesh. The sample factories were selected from a list collected by the Bangladesh Garments Manufacturer and Exporter Association (BGMEA) of garment factories situated in Dhaka City. Factories are located within various areas of Dhaka City, and workers' benefits vary from factory to factory depending on size and location. To ensure the representation of factories from all areas, the researcher(s) identified eight different zones of Dhaka City where many factories were located. One factory from each area was chosen for this study. Interviews were conducted with 71 research participants including 32 workers, 16 employers/managers, six representatives of six workers' unions, three representatives from the government (Ministry of Labor, Directorate of the Inspection of Factory and Establishment, Bangladesh Export Promotion Zone Authority), two representatives from the Bangladesh Garments Manufacturers and Exporters Association, two NGO representatives, six representatives from buyers/brand companies, and two labor experts. It is important to note that company authorities generally do not welcome researchers or journalists fearing that malpractice existing in the factory will be disclosed. It was thus difficult to get access to the workers. Three factories (out of eight) did not 
allow the author to speak with the workers. The authorities did not provide any explanation for their denial, but it is evident from conversations with the employers that they fear that discussion with outsiders contains a possible threat of losing export contracts. ${ }^{2}$ Surprisingly, workers have also been reluctant to talk with visitors both inside and outside the factory. Inside the factory, workers are frightened of losing their jobs and do not have free time to talk because they are required to fulfill quotas (targets of production given by employers). Outside the factory, these women are scared to talk to any unknown person, especially a man. In this context, it was challenging for the researcher to gain access to the workers. To overcome these barriers, the author stood in front of the factories during closing time, accompanied by a female graduate who spoke with female workers. The researcher noted the home addresses of the workers who showed interest in participating and visited the workers' residences during weekends for interviews. Female workers selected for interviews were between the ages of 18 and 45 and had at least 2 years of experience working in the RMG industry. ${ }^{3}$

The data for this study were collected primarily through in-depth interviews. The researcher(s) used different interview schedules for each type of participant (e.g. workers, employers, union leaders) to acquire appropriate information. The interview schedules were developed by incorporating semi-structured, open-ended questions. Some of the questions included: "What are the reasons for female preferences in recruiting workers?"; "What types of problems do female workers face in the workplace?"; "How is the gender segregation of work and wage discrimination maintained?"; and "How are gender-based beliefs (gendered discourses) used to justify the differential treatment of male and female workers?" Although a vast majority of the primary data was generated through qualitative interviews, some ethnographic techniques (observation and conversations with local people) added significant value to the research. The researcher stayed 9 months in the research area and spent a large amount of time engaging in informal talks with the local people residing in workers' residential areas and with the workers' family members. The goal was to obtain respondents' opinions on female employment in the RMG industry. The researcher also arranged four "focus group discussions" (FGD) involving workers from factories and local people. Moreover, during fieldwork in Bangladesh, the author attended a number of workers' conventions, seminars and symposiums arranged by different trade unions and NGOs involving garment workers, civil society members, employers, workers' union leaders, and researchers. All events were additional avenues to learn about the experiences of workers from most factories, including the selected factories for this study. The study was further substantiated by various secondary sources. After arrival in Dhaka, the researcher spent the first 4 weeks collecting document information (annual reports, brochures, periodicals,

\footnotetext{
${ }^{2}$ Buyer companies often perform audits and inspections through third parties to monitor codes of conduct. Thus, if outsiders wish to visit the factories, employers assume that they may be sent by buyers to observe labor practices at the factories.

${ }^{3}$ Although the local law and buyers' code of conduct do not allow children below 18 years of age, many workers were under this age and had provided a false birth certificate to obtain employment because the job was essential for their survival.
} 
bulletins, and study reports) from concerned ministries and offices, such as BGMEA, BEPZA, NGOs, and research organizations.

Substantial parts of this paper are drawn from the doctoral thesis of the first author. Therefore, ethical issues were considered throughout the study with the prior approval of the ethics committee of the university. The researcher used informed consent protocols and opening statements explaining the purpose and use of this research. Keeping in mind the risk of retaliation on workers by employers, all interviews were conducted in the workers' residential areas to maintain confidentiality from the employers. Similarly, the names of the participants and/or employing agencies were not mentioned in the study. For handling the data, symbolic codes and synonyms were used. The same ethics and procedures were also maintained for employers and enterprises. After selecting the eight factories, the author sought permission from the relevant authority to visit the factories by explaining the purpose of the visit.

\section{Women's employment in Bangladesh readymade garment industry}

Bangladesh is a developing country, and its economy is highly dependent on agriculture. Historically, Bangladesh has had slow industrial growth. At the time of independence in 1971, only $18 \%$ of total industries were owned by Bangladeshi industrialists, $47 \%$ by Pakistani industrialists, $34 \%$ were state-owned and only $1 \%$ were owned by foreign investors (Rashid, 2006). The expansion of industrial sectors in Bangladesh was led by RMG production from the first half of the 1980s, and, by the end of the decade, it had become a prime source for export earnings fostered by new industrial policy and international demands (Kabeer \& Mahmud, 2004). The Multi-Fiber Agreement (MFA) was a key instrument that fostered the rapid growth of the RMG industry. The imposition of quotas under this agreement led industrialized countries ${ }^{4}$ to search for a quota-free location to set up garment manufacturing plants (Rahman, Bhattacharya \& Moazzem, 2008). With tariffs and import quotas, free access to markets in the USA, EU, and other developed countries under the Generalized System of Preference (GSP), trade policy, and, above all, availability of cheap labor in Bangladesh, foreign investment, which contributed to the rapid growth of RMG factories in Bangladesh, became attractive (Ahmed, 2009). According to BGMEA, 4 million people were employed in Bangladesh in 2012 compared with only 0.04 million workers in 1983 (Table 1). The economy of Bangladesh has become highly dependent on this industry. While the total export earnings from the RMG sector were US\$13.57 million in 1984, they reached US\$12,496.72 million in 2010 and the total share increased from $3.89 \%$ to $77.12 \%$ in the respective years (Bangladesh Export Promotion Bureau, 2011). The share of export earnings from this sector was $75.1 \%$ in $2005 / 06$ (Ahmed, 2009).

\footnotetext{
${ }^{4}$ This refers to developed countries, particularly USA, Canada, Australia, Japan, and European countries, that are more involved in capital-intensive products (computers, automobiles) than labor-intensive products (RMG, shoes, leather, toys).
} 
Table 1 Total number of garment factories and employment (FY1983-2012)

\begin{tabular}{lllll}
\hline & & \multicolumn{2}{l}{ Employment (million) } & \\
\cline { 3 - 4 } Years & Number of enterprises & Both (men and women) & Women & Percentage of women \\
\hline $1983-84$ & 134 & 0.040 & 0.034 & 85 \\
$1985-86$ & 594 & 0.198 & 0.16 & 85 \\
$1990-91$ & 834 & 0.402 & 0.34 & 85 \\
$1995-96$ & 2353 & 1.290 & 1.08 & 90 \\
$2000-01$ & 3480 & 1.800 & 1.44 & 85 \\
$2005-06$ & 4220 & 2.200 & 1.87 & 85 \\
$2009-10$ & 5063 & 3.600 & 2.88 & 80 \\
$2010-11$ & 5150 & 3.600 & 2.88 & 80 \\
$2011-12$ & 5400 & 4.000 & - & - \\
\hline
\end{tabular}

Source: Bangladesh Garment Manufacturer \& Exporter's Association (BGMEA), 2013.

\section{Gendered discourses in the RMG industry: findings of the study}

A great share of the labor force in the Bangladesh RMG industry is constituted by women, and this number is gradually increasing. Garment products are mostly exported to US and European markets through international buyers, such as Nike, Walmart, Kmart, JC Penney, Sears, TESCO, ZARA, Target, Marks \& Spencer, and the GAP (BGMEA, 2013). Price elasticity in global markets directly impacts the firms where products are made. Therefore, the employment pattern and workers' rights in the Bangladesh RMG industry are influenced by the global market. In addition to global economic forces of cheap labor, cultural beliefs and practices also influence employment patterns and labor rights in Bangladesh. An important finding from this study revealed that a gendered culture dominates the hiring and production processes, causing greater increase in the female labor force and leading to the violation of workers' rights; as presented in the following sections.

\section{Women are docile, patient, and sincere}

The most prevalent cultural belief persisting in the RMG sector is that women are docile, and patient, and their nimble fingers make them suited to garment work. During interviews, all male interviewees, including employers, union leaders, and NGO workers, noted that women's fingers are soft and nimble so they can sew very efficiently. For instance, one employer stated that “women's nimble fingers are more suitable for sewing work. This sort of job suits women's traditional working of sewing and they are faster in sewing than men." They further stressed that sewing is a very monotonous job that requires great care and sincerity, and that women possess these qualities. Conversely, workers and female labor experts argue that female preference does not merely happen for their nimbleness, but it primarily happens due to their patience and tolerance. Employers can put pressure on female workers to reach a higher production target, and usually get no reaction from the female workers. According to workers' testimony, after 
working long periods of time (12-14 h), women become exhausted but do not receive a break outside of lunch. The women stated that if they make any mistakes in their work due to their fatigue, they have to face abusive words and even physical assault from senior bosses. However, female workers never raise their voices against injustice. Interviews with management reinforce the workers' claim. A human resource manager said:

Generally, production capacity of a male worker is higher than a woman but male workers are very chaotic. The natural trait of a man is aggressive, which very often creates problems in the factory. They try to organize workers and place undue demands to the authority. If male employees go over $40 \%$ it is very difficult to run the factory. Therefore, we prefer woman workers than male.

This docility of women is not, however, a natural endowment. But rather is naturalized, at least partly, because of socialization (Ahmed, 2004) and their vulnerable position in the labor market (Mahmud, 2004). Female workers are forced to be docile, what Elson and Pearson (1997, p. 195) call "supposed docility". One worker says:

We are bound to be sincere and attentive because we will not be allowed to leave the factory until we fulfill our quota. If we make any mistake, they will use abusive and vulgar words, like, "Hi lady is your vagina wet now?" Did your Vatar [husband in vulgar way] not give you any input at night? They even call our parents names.

Workers cannot protest because making demands or taking a stand against this injustice may jeopardize their employment (Mahmud \& Kabeer, 2003). According to one female worker:

I have no way but to be docile and submissive because, if I make any protest, I will certainly lose my job. Can you imagine what would happen then! If I lose my job, I have most likely to starve.

The above descriptions clarify that employers prefer female workers due to their nimbleness, patience, and docility, associated with high productivity, which in turn reduces production costs and increases profit margin.

\section{Women accept lower wages}

There is a widespread notion in the RMG sector that women ask for lower wages than men. This belief is associated with the secondary status of women in the labor market $\left(\right.$ Sarker, 2007) ${ }^{5}$. Persuaded by patriarchal cultures, which define differentially-gendered roles of male breadwinners and female caregivers, women are usually reluctant to be involved in employment (Feldman, 2001; Hossain et al., 2012). However, in recent decades many women have been forced to enter the labor market to make a supplementary contribution to the traditional family (Kibria, 1995; Kabeer, 2004; Paul-Majumder \& Begum, 2006). In addition, many divorced or single mothers have migrated to urban areas for work as a means of survival for their family members (Kabeer, 2004). Employers take advantage of this social vulnerability by employing women temporarily and paying them

${ }^{5}$ Culturally it is believed that women are not breadwinners but secondary earners in the family. Therefore, it is not very important whether their wages are sufficient. 
low wages. Female workers accept low wages for their survival, which is reflected in this worker's statement:

I have two children and I am solely responsible to feed them as my husband left me behind and married another woman. If I don't work, my children and I will starve. So it is more important for me to have work, regardless of whether the work is temporary or permanent or even poorly paid.

Even though employers exploit female workers by providing low wages and few labor benefits, the employers sometimes boast, thinking they are doing the women a great favor, saying that, if these female workers were not employed, they would starve or would be involved in unethical jobs. Islam's study (2008) found a similar rationalization of exploitation in the shrimp industry of Bangladesh. Employing women temporarily is a strategic way of making their labor cheap.

\section{Women are less mobile}

This study shows that, while there is greater possibility for skilled and trained workers to get jobs with higher wages if they are able to shop around for work in different factories, the mobility of female workers is relatively low. Due to a delayed payment system, workers cannot change their workplace (Paul-Majumder \& Begum, 2006). All female workers in this study replied that wage payments are usually delivered at the middle of the subsequent month. During a focus group discussion, one of the workers said:

We earn too little to survive (US\$55-60 per month). We can look for a better place in other factories but our employers force us to be here by giving our payment at the middle of the subsequent month. If we leave at the middle, we will lose the wage for 15 days and overtime work. Then how will we manage our daily expenditures if we don't get payment for a month?

Employers have acknowledged the issue of delayed payment but have tried to justify their action by claiming that binding measures controlling the movement of workers are necessary as the workers are very unstable by nature. Employers intentionally follow delayed payment systems to restrict workers' movement because, if workers leave the factory, employers have to pay higher amounts to employ new workers, and it may also hamper production.

\section{The myth of the smart and golden girl}

The topic of the feminine image recurs as an important issue during interviews. It is often claimed that the "smart girl is the golden girl". ${ }^{6}$ A former worker, currently working in Awaj Foundation (an NGO devoted to women garments workers), said:

Bangladesh earns major share of foreign currency (gold) by exporting RMG products to many developed countries. The only component of production that Bangladesh has and con-

${ }^{6}$ This term was used first by Siddiqi (2009). Formerly, jute was the main good for foreign currency earnings and hence was called the "Golden Fiber of Bangladesh". During 1990s, it was replaced by RMG products, whose contribution to foreign currency earning is about $77 \%$. Therefore, for having a greater contribution in foreign currency earning, women workers feel proud to introduce themselves as golden girls. 
tributes to the sharp increase of foreign currency earning is the cheap labor constituted by young girls. So they are the golden girls of Bangladesh.

A member of parliament also has affirmed that RMG workers should be acknowledged as the golden labor of Bangladesh because they have coined the term "made in Bangladesh" in global market. ${ }^{7}$ During the visit to the factories, the researcher rarely found a woman above the age of 40, the majority being between 15 and 35 years (see also Paul-Majumder \& Begum, 2006; Rahman et al., 2008). Female workers note that factory management gives preference to young, smart women in the recruitment process. Employers' views also support the preference of young girls as workers over older women. They said that productivity of young girls is higher than older women because young girls are more energetic than older women. The study reveals that smartness is not used to denote higher production of workers but sexual pursuit is. During "focus group discussions", a 45-year-old woman, mother of two young female garment workers, said that owners never employ an older woman who is less attractive. Female sexuality is an important characteristic for getting a job, as well as getting privileges at work. One interviewee said:

If anyone has big "buk" (breast) she doesn't need anything else to get a job in the factory. She will get higher salary, early increment; even though she doesn't work too much. Once I asked my supervisor for leave but he refused. Then my colleague asked me to give the form to her to manage the boss. I asked her, is he your Vatar [husband, in vulgar way] that he will agree if you request him? O ma (in surprising gaze) truly she could manage. Always she gets privilege because she is more attractive than many of us.

It is reported that young, unmarried, and single women are more likely to experience sexual harassment by managers and other senior bosses, but this harassment remains undisclosed to others. Victims are unwilling to make a claim against their bosses to the higher authorities because they see no possibility of getting justice (Siddiqi, 2004). On the contrary, if the issue of their sexual harassment becomes public, there is also the possibility of losing their jobs as a consequence of disclosing their bosses' crime (Danneker, 2002). Moreover, the publicity of rape has serious negative repercussions on a victim's life. She becomes a matter of public gossip and teasing that subverts her social status. If it becomes public, the victim escapes from public rebuke either through quitting the job or sometimes committing suicide (Siddiqi, 2004). In this precarious juncture, what is ironic is that the perpetrator of the crime remains untouched, while the victims get double punishment. Female workers face maltreatment by the factory owners, but they can rarely lodge a protest because of differential power relations. As a worker and a woman, they hold less power and remain what Spivak (1988) calls a "subaltern subject". Workers' testimony contradicts the employers' views; while workers wish to be recognized as "golden girls" for their great contribution in foreign currency earnings, employers treat them in a sexist way, which increases their

${ }^{7}$ From a speech given on "Budget 2013-14 of Bangladesh" in Parliament by Barrister Andalib Rahman (June 17, 2013). 
vulnerabilities. The young and smart girls are the instruments for higher production and reducing production costs, and at the same time help to fulfill the sexual desire of their cunning employers.

\section{Women are less likely to join trade unions}

Another perceived notion that influences owners to prefer female workers is that women are less likely to join trade unions. Scholars have contended that the right to form and join in collective bargaining helps to negotiate fair wages and improved labor conditions (Norris, 2012; Shen \& Benson, 2008; Simpson, 1994). This right is completely violated in the Bangladesh RMG industry. During fieldwork, the researcher(s) found some trade union federations such as the Bangladesh Independent Garments Union Federation (BIGUF), the Bangladesh Garments Workers Federation, the Bangladesh Centre for Workers' Solidarity, the Bangladesh United Garments Workers Federation, and the Garments Workers Unity Forum. However, this study has found little evidence of workers' involvement in these trade unions, and female workers' participation is much lower than that of male workers. The major tasks performed by unions are negotiating with employers for increased wages, supporting workers in filing cases in labor court to get unpaid wages, creating awareness among workers about labor rights issues, and arranging training programs for skills development. Some of the unions also work as NGOs (e.g. Karmajibi Nari), operating schools for children of workers and hostels for working women. According to statistics, there are 80 registered trade unions and 15 trade union federations in the Bangladesh RMG sector where memberships are 50,149 (only $2 \%$ of the total employed workers in this sector) (Table 2).

This study found only one worker (out of 32 interviewed workers) who was active in union activities; however, she did not take part in any activities within the factory during working hours. She participated around her residential area during holidays or after work. When the issue was raised among female workers, all of them expressed their disinterest for fear of losing their jobs. One employee noted:

I know that the union is helpful for workers. The union can bargain with the employers to implement workers' demand and for this reason employers do not prefer any existence of trade union. I feel the need to join the trade union but in fact I cannot. If I join today [and the news goes to the employer], tomorrow I will have no job here. Given this context, how do I take the risk of joining trade union?

Table 2 Total number of registered trade unions in Bangladesh (Upto June 2007)

\begin{tabular}{lclc}
\hline Categories & $\begin{array}{l}\text { Total number of } \\
\text { federations }\end{array}$ & $\begin{array}{l}\text { Number of unions } \\
\text { included }\end{array}$ & $\begin{array}{l}\text { Total } \\
\text { membership }\end{array}$ \\
\hline National Federation & 32 & 1264 & $1,236,665$ \\
Industrial federation & 108 & 721 & 640,221 \\
Garments federations & 15 & 80 & 50,149 \\
Basic union & 5242 & - & $2,069,614$ \\
\hline
\end{tabular}

Source: Faruque (2009). ILO, Geneva. 
They cannot even share their sufferings and vulnerabilities with others. ${ }^{8}$ During the interview, female workers were found to be afraid of losing their jobs. They tried to hide any information about the employers that could be negative. It is well known to them that disclosure of any internal information about the factory would certainly lead them to be fired from their jobs. It is telling that in every apparel factory there were some preselected workers to speak for others. They were trained by the management to speak only in favor of the factory management and not in favor of workers. The reason for such a paradoxical role was articulated and revealed by one worker in the following way:

The authority asks us not to say anything negative about the factory. They tell us that if we tell negative things, the factory will be closed and then we will lose our job. If we don't obey their request and instead share our experiences, we may be fired. Thus, we don't tell anything negative to others. When Babura [visitors] come and ask us about our problems, we tell them we are fine.

Perverted and corrupted roles of the union leaders is also responsible for lower participation of workers. Some of the workers reported that trade union leaders do nothing for the welfare of the workers; rather they serve the interest of the owners or of the political parties with whom they are affiliated (see Kabeer \& Mahmud, 2004). On the other side, union organizers are harassed by the employers. Many of the union leaders said that they fear being arrested by the law enforcement agencies because employers/police file false cases against union leaders (see also Danneker, 2002). Union leaders and labor scholars reported that the harassment of union organizers and the firing of workers are strategic weapons of employers, stopping workers from joining and organizing trade unions. It generates panic among the mass workers, particularly among women, and they feel reluctant to take part in union activities. In the absence of unions, employers easily disrespect labor rights. Thus, employing female workers becomes a strategic way of reducing production costs.

\section{Discussion of the findings}

The principal question of this paper has been to explore the kind of gendered discourses that are practised in hiring and production processes that contribute to the feminization of the workforce. Referring to this question, findings show various gendered discourses; women are docile and sincere in their jobs, hardly ever change their jobs, are satisfied with low labor benefits including wages, are less likely to join trade unions, and create fewer disturbances in the factory (Paul-Majumder \& Begum, 2006). All of these arbitrarily constructed and practised beliefs in the factories are consistent with the feminization of the workforce (Elson \& Pearson, 1981; Caraway, 2005). The research findings clearly indicate that female workers are preferred by employers (see also Acker, 2004; Nash \& Fernandez-Kelly, 1983). Almost $80 \%$ of workers in the RMG sector are women, and this number is gradually increasing. This is consistent with the first feature of the

${ }^{8}$ It is true that the research participants were female workers, but the interviewer had to follow different strategies to reach them, as discussed in the methodology section. 
feminization of the workforce (Mahmud \& Kabeer, 2003). The second feature of feminization is the flexibility of labor force, which is also influenced by gendered discourses. The belief that women are "secondary earners of families" influences the formation of a part-time and temporary workforce. The gendered division of labor is maintained and influenced by gender-based myths. Although a man and a woman can produce the same amount of work without compromising the quality, women are segregated to particular jobs that are poorly remunerated (Hossain, 2012). The most crucial feature of globalization that is associated with feminization and labor flexibility is the exploitation of labor rights. Following this feature, this study deals with how gendered discourses contribute to labor vulnerability and exploitation. The findings of this study show that manufacturing enterprises' preference for female workers is the strategic choice of employers. Employers prefer women because it is more cost efficient for them. Employers can recruit women temporarily because women have a greater need for the jobs and are more willing to work even with the lack of job benefits. It is evident that RMG factories in Bangladesh are characterized by poor working conditions, insufficient wages, heavy workloads, and a lack of labor benefits (Ahmed, 2004). Thus, employers can easily exploit women by denying their labor rights. Workers receive sweatshop wages that are inadequate for basic human necessities, such as food, shelter, and medicine at local prices (FernandezKelly, 1997; Mitlo \& Beaulieu, 1998). It is also reported that female workers are being cheated by a number of wage practices, particularly in overtime work (Varley, 1998). Sexual harassment by bosses frequently take place (Siddiqi, 1991). However, women cannot resist the injustices because of a lack of women's agency (Danneker, 2002). Women's vulnerable and temporary position in the labor market inhibits them from joining trade unions. The constant fear of losing their jobs deters them from being united. In the absence of unions, female workers cannot force employers to ensure labor rights. Fighting or bargaining with a male is regarded as socially indecent for a woman in the patriarchal society of Bangladesh and employers use this disadvantaged position of women, which Arizpe and Aranda (1981) call the "comparative advantages of women's disadvantage". ${ }^{9}$ Employers and management staff report that male workers can produce more than female workers, but they prefer female workers because female workers are more easily controlled. The hard and strict behavior of men can discipline women because women have less power (Weaver, 2000).

\section{Gendered discourse, labor vulnerability and social work response}

Existing literature shows that globalization has brought uneven consequences to Bangladesh. Feminization, labor flexibility and substandard employment are consequences of neoliberal globalization, which stipulates the rise of privatization, transnational corporations, competition, and global consumption (Wilson, 2012). Scholars argue that poor

${ }^{9}$ Women have few opportunities to become educated and skilled and consequently have fewer job opportunities. Having no alternative source of employment, women are bound to work in the garment industry though it is poorly paid. Employers take advantage by paying low wages and offering few labor benefits. 
working-class people, particularly women, suffer from capitalist patriarchal exploitation (Lim, 1997). Since providing services to vulnerable constituents of the global population is a significant area of practice for social work educators and practitioners, they can play a lead role in advocating change, and in organizing and networking female workers facing the challenges of globalization through effective social dialogue involving the various stakeholders, taking into account the particular context of the society. Social justice theorists, (e.g. Rawls, Pogge, and Sen) have argued that it is the moral responsibility of individuals as well as the state to intervene, reducing injustice so that underprivileged and disadvantaged people can gain an advantage. Social justice is one of the core values of social work, including service, personal dignity and worth, and the importance of human relations, integrity, and competence (Holscher, 2012). The guiding notion is that "social workers challenge social injustice". In the description of the ethical principle of social justice, NASW states:

Social workers pursue social change, particularly with and on behalf of vulnerable and oppressed individuals and groups of people. Social workers' social change efforts are focused primarily on issues of poverty, unemployment, discrimination, and other forms of social injustice. These activities seek to promote sensitivity to and knowledge about oppression and cultural and ethnic diversity. Social workers strive to ensure access to needed information, services, and resources; equality of opportunity; and meaningful participation in decision making for all people (NASW, 2013).

Clearly, it is the ethical responsibility of social workers to respond to injustices, whether rooted in the national or global level. Young (2006) has proposed a social connection model addressing structural injustices which identifies four parameters (power, privilege, interest, and collective ability) for individual responsibility in combating social and global injustices. Since the social work profession is embedded in moral and social values of helping vulnerable people, social workers bear the collective responsibility of assisting vulnerable people and to work to bring social justice to the society. According to Wilson (2012, p. 20), social workers have the ability to bring a range of roles and skills to build a more equitable and sustainable globalization process. She notes further:

Social workers can bring important conceptual and practical skills to work both on the terrain of the war of ideas and on the terrains of political and economic action ... social workers are uniquely equipped both to engage in social policy process (formulation, critique, change) and to be effective allies of groups, organizations, and movements addressing issues of human rights and social justice (Wilson, 2012, p. 21).

Securing workers' rights in the context of globalization, intervention at the international, national and local levels is needed. Popular movements at the international level can be key instruments to force multinational corporations to respect labor rights. Social workers can promote collective political action by becoming allies with international movements (Holscher, 2012). At the national level, social workers can influence legislative processes by endorsing political campaigns, and at the local level they can make workers aware and organize them by promoting educational forums, speakers, and 
discussions, and engage in writing letters to bring issues to the attention of legislators (Polack, 2004).

\section{Concluding remarks}

The findings of this research explore how women are doubly vulnerable in the global production system through the economic choice of cheap labor and gendered discourses of work, both of which collaboratively contribute to form a feminized and flexible workforce. The reason for preferring female workers is that it substantially helps producers to minimize the cost of production. This is because they are able to offer women lower compensation and benefits compared with their male counterparts. Similarly, unfair compensation and benefits are rationalized and justified by gendered discourses of work. Employers are inclined to practise these gendered discourses of work because it frees them from taking the responsibility of providing labor benefits. Thus, feminization of the workforce and labor vulnerability in global factories result from the search for cheap labor and gendered beliefs, alternatively capitalism and patriarchy, both of which serve the purpose of global capitalists.

This study also affirms that gendered discourses of work are not created artificially by employers; rather they are imbedded in the sociocultural practices of Bangladesh. The closing of garment industries would seem to be an alternative to the problem, but this is more likely to trigger worse challenges for women in terms of their access to paid employment. In order to protect labor rights, the solution is not to close down the industries, but to recognize and resolve the unjust labor practices. The development of women's agency is of crucial importance to protect female workers from the oppression of capitalist patriarchy.

\section{References}

Acker, J. (2004). Gender capitalism and globalization. Critical Sociology, 30, 17-41.

Ahmed, F. E. (2004). The rise of Bangladesh garment industry: Globalization, women workers and voice. Feminist Formations, 16(2), 34-45.

Ahmed, N. (2009). Sustaining ready-made garment exports from Bangladesh. Journal of Contemporary Asia, 39(4), 597-618.

Arizpe, L., \& Aranda, J. (1981). The comparative advantages of women's disadvantages: Women workers in the strawberry export agribusiness in Mexico. Signs, 7(2), 453-73.

Bangladesh Export Promotion Bureau (BEPB). (2011). Ministry of Trade and Commerce. Dhaka, Bangladesh: People's Republic of Bangladesh.

Bangladesh Garment Manufacturer and Exporter's Association (BGMEA). (2013). Retrieved January 20, 2013, from http://www.bgmea.com.bd/home/pages/TradeInformation

Barrientoes, F., \& Kabeer, N. (2004). The gender dimension of the globalization of production. Working paper No. 17. Geneva: International Labor Organization.

Boserup, E. (1970). Women's role in economic development. New York: St. Martins Press.

Caraway, T. L. (2005). The political economy of feminization: From cheap labor to gendered discourses of work. Politics \& Gender, 1, 399-429. 
Danneker, P. (2002). Between conformity and resistance: Women garment workers in Bangladesh. Dhaka: University Press Limited.

Elson, D., \& Pearson, R. (1981). Nimble fingers make cheap workers: An analysis of women's employment in third world export manufacturing. Feminist Review, 7, 87-107.

Elson, D., \& Pearson, R. (1997). The subordination of women and the internationalization of factory production. In N. Visvanathan, L. Dugan, L. Nisnof \& N. Wiegersma (Eds.), The women gender and development reader (pp. 191-203). London: Zed Books.

Faruque, A. A. (2009). Current situation and evolution of industrial relation system in Bangladesh. Geneva: ILO.

Feldman, S. (2001). Exploring theories of patriarchy: A perspective from contemporary Bangladesh. Signs, 26(4), 1097-127.

Fernandez-Kelly, M. P. (1997). Maquiladoras: The view from the inside. In N. Visvanathan, L. Dugan L. Nisnof \& N. Wiegersma (Eds.), The women gender and development reader (pp. 20315). London: Zed Books.

Holscher, D. (2012). Social justice. In L. M. Healy \& R. J. Link (Eds.), Handbook of international social work: Human rights, development and the global profession (pp. 44-51). New York: Oxford University Press.

Hossain, N. (2012). Exports, equity and employment: the effects of readymade garments manufacturing employment on gender equity in Bangladesh. A background paper for World Development Report, 2012.

Hossain, M. I., Al-Amin, M., \& Alam, M. J. (2012). NGO interventions and women development in Bangladesh: Do feminist theories work? The Hong Kong Journal of Social Work, 46(1/2), 13-29.

Islam, S. M. (2008). From sea to shrimp processing factories in Bangladesh: Gender and employment at the bottom of a global commodity chain. Journal of South Asian Development, 3(2), 211-36.

Kabeer, N. (2004). Globalization, labor standards and women's rights: Dilemmas of collective (in) action in an interdependent world. Feminist Economics, 10(1), 3-35.

Kabeer, N., \& Mahmud, S. (2004). Globalization gender and poverty: Bangladeshi women workers in export and local markets. Journal of International Development, 16, 93-109.

Kanji, N., \& Sen, K. M. (2001). What does the feminization of labor mean for sustainable livelihoods? London: Bulletin on World Summit on Sustainable Development, The International Institute for Environment and Development (IIED).

Kibria, N. (1995). Culture, social class and income control in the lives of women garments workers in Bangladesh. Gender and Society, 9(3), 289-309.

Lim, L. Y. C. (1997). Capitalism, imperialism and patriarchy: The dilemma of third-world women workers in multinational factories. In N. Visvanathan, L. Dugan, L. Nisnof \& N. Wiegersma (Eds.), The women gender and development reader (pp. 216-29). London: Zed Books.

Mahmud, S. (2001/04). The labor use of women in rural Bangladesh. In R. Sobhan \& N. Khundker (Eds.), Globalization and gender: Changing patterns of Women's Employment in Bangladesh (pp. 25-63). Dhaka: University Press Limited.

Mahmud, S., \& Kabeer, N. (2003). Compliance versus accountability: Struggles for dignity and daily bread in the Bangladesh garment industry. The Bangladesh Development Studies, 29(3 \& 4), 21-46.

Marchand, M. H., \& Runyan, A. S. (Eds.). (2000). Gender and global restructuring: Shifting, sites, and resistances. London: Routledge. 
Mitlo, C., \& Beaulieu, D. (1998). Sweatshops: Who pays the price? Co-op America Quarterly, 58(Fall), 12-26.

Momen, M. (2006). Empowering whom? Garment workers in Bangladesh. Empowerment: A Journal of Women for Women, 13, 23-38.

National Association of Social Workers (NASW). (2012). Code of Ethics of Social Workers. Retrieved on December 7, 2012 from http://www.naswdc.org/pubs/code/code.asp

Nash, J., \& Fernandez-Kelly, M. P. (1983). Women, men and the international division of labor. Albany: SUNY Press.

Norris, L. (2012). Protecting workers' rights. Huffington Post, September 19.

Paul-Majumder, P., \& Begum, A. (2006). Engendering garment industry: The Bangladesh context. Dhaka: University Press Ltd.

Polack, R. J. (2004). Social justice and the global economy: New challenges for social work in the 21st century. Social Work, 49(2), 280-90.

Rahman, M., Bhattacharya, D., \& Moazzem, K. G. (2008). Bangladesh apparel sector in post MFA era: A study on the ongoing restructuring process. Dhaka: Centre for Policy Dialogue.

Rashid, M. A. (2006). Rise of readymade garment industry in Bangladesh: Entrepreneurial ingenuity or public policy. Paper presented at the workshop on Governance and Development, Dhaka.

Razavi, S. (2002). Shifting burdens: Gender and agrarian change under neo-liberalism. Bloomfield, CT: Kumarian Press.

Safa, H. (1986). Runaway shops and female employment: The search for cheap labor. In E. Leacock \& H. Safa (Eds.), Women's work (pp. 58-71). New York: Bergin and Garvey.

Sarker, S. (2007). Globalization and women at work: a feminist discourse. A paper presented at International Feminist Summit, Townsville, Australia, Southbank Convention Centre, July 17-20.

Shen, J., \& Benson, J. (2008). Tripartite consultation in China: A first step towards collective bargaining? International Labour Review, 147(1/2), 231-48.

Siddiqi, D. (1991). Discipline and protect: Seclusion and subversion among women garment workers in Bangladesh. Grassroots: an Alternative Development Quarterly, 1(2), 4-12.

Siddiqi, D. (2004). The sexual harassment of industrial workers: Strategies for intervention in the work place and beyond. Working paper no. 26. Dhaka, Bangladesh: Centre for Policy Dialogue and UNFPA.

Siddiqi, D. (2009). Do Bangladeshi workers need saving? Sisterhood in post-sweatshop era. Feminist Review, 91, 154-74.

Simpson, W. R. (1994). The ILO and tripartism: Some reflections. Monthly Labour Review, 117(9), 40-45.

Spivak, G. C. (1988). Can the subaltern speak? In C. Nelson \& I. Grossberg (Eds.), Marxism and the interpretation of culture (pp. 271-313). Basingstoke: Macmillan Education.

Standing, G. (1989). Global feminization through flexible labor. World Development, 17(7), 1077-95.

Varley, P. (Eds.). (1998). The sweatshop quandary: Corporate responsibility on the global frontier. Washington, DC: Investor Responsibility Research Centre.

Weaver, F. (2000). Latin America in the World Economy: Mercantile Colonialism to Global Capitalism. Boulder, CO: Westview Press.

Wilson, M. (2012). Globalization. In L. M. Healy \& R. J. Link (Ed.), Handbook of international social work: Human rights, development and the global profession (pp. 16-23). New York: Oxford University Press.

Young, I. M. (2006). Responsibility and global justice: A social connection model. Social Philosophy and Policy, 23(1), 102-30. 